\title{
Directions from the GET-GO. On the syntax of manner-of-motion verbs in directional constructions*
}

\author{
Marcel den Dikken \\ CUNY Graduate Center. Linguistics Program \\ MDen-Dikken@gc.cuny.edu
}

Received: April 122010

Accepted: July 302010

\begin{abstract}
Directional resultatives show puzzling syntactic restrictions. In Romance, broadly speaking, they do not occur at all with manner-of-motion verbs. In Dutch, directional resultatives with mannerof-motion verbs usually force postpositional order in the directional PP - but prepositional order is grammatical under circumstances that have so far defied a unified and insightful account. Focusing primarily on Dutch, this paper presents an analysis of directional resultative constructions and the syntactic representation of manner of motion which is centred around the following main claims: (a) directional resultative constructions with manner-of-motion verbs can in principle be built on either of two structures, one featuring the light verb GO and the other the light verb GET; $(b)$ while both light verbs take a small-clausal complement, GET takes one that is headed by a particle; $(c)$ the particle in GET-constructions can license a null directional $\mathrm{P}$ in the structure of directional PPs built on a non-inherently directional adposition, and deliver prepositional order; (d) the absence of a particle in GO-constructions forces the null directional P in directional PPs built on non-inherently directional adpositions to either incorporate into GO or have the locative $\mathrm{P}$ embedded in its complement to raise up to it; $(e)$ manner-of-motion verbs have a MANNER component adjoined to GO/GET; $(f) \mathrm{P}$-incorporation into MANNER-modified GO/GET is inadmissible (due to a ban on multiple adjunction to the same head); $(g)$ in GO+MANNER structures, a null directional $\mathrm{P}$ can hence be licensed only by having a locative $\mathrm{P}$ raise up to it; $(h)$ raising of a locative $\mathrm{P}$ up to a directional $\mathrm{P}$ results in postpositional word order in Dutch, whereas the absence of raising of $\mathrm{P}_{\mathrm{Loc}}$ up to $\mathrm{P}_{\text {Dir }}$ delivers prepositional surface order.
\end{abstract}

Key words: directional resultatives, manner-of-motion verbs, postpositions, Dutch.

* I would like to thank the organisers of the 10th Seoul International Conference on Generative Grammar (Seoul, 17-20 July 2008) and the conference on Expressions of Posture and Motion in Germanic Languages (Brussels, 24 October 2008) for inviting me to speak specifically on argument structure, a topic that I had not worked on in any direct way for about a decade (since the completion of my work on particles, published in Den Dikken 1995, and my joint work with Rint Sybesma on serial verbs, nominalisations and middles; see Den Dikken \& Sybesma 1998). The incentive to return to the topic has turned out to be very stimulating. Equally stimulating were the many discussions on argument structure I had with Cristina Real Puigdollers, who spent the spring 2008 term at the CUNY Graduate Center as a visiting student. Finally, I would like to gratefully acknowledge the constructive and insightful remarks made by an anonymous reviewer for the Catalan Journal of Linguistics, and thank Jaume Solà for inviting me to contribute this piece to the journal. I have benefited greatly from all the feedback and discussion; but I am still a wanderer in this area. 


\section{Table of Contents}

1. The distribution of prepositional and postpositional directional PPs in Dutch

2. The central proposal

3. To GET or to GO someplace, with manners or without

4. On manners, means, and causes
5. Where are your manners?

- The causative/inchoative alternation

6. Going beyond Dutch

7. In closing

References

\section{The distribution of prepositional and postpositional directional PPs in Dutch}

\subsection{Simple coming and going}

Many Dutch directional PPs can in principle be either prepositional or postpositional. The word-order alternations in (1) and (2) illustrate this.

(1) a. hij gooide het boek in de haard

$\left(\right.$ Dutch $\left.^{1}\right)$

he threw the book in the fireplace

b. hij gooide het boek de haard in

he threw the book the fireplace in

both: 'he threw the book into the fireplace'

(2) a. hij gooide het boek uit het raam

he threw the book out the window

b. hij gooide het boek het raam uit

he threw the book the window out

both: 'he threw the book out the window'

The Dutch simple motion verbs gaan 'go' and komen 'come' allow prepositional directional resultatives with non-inherently directional Ps (such as in 'in(to)' and uit 'out (of)') as well, but only under highly restricted circumstances: in their literal verb-of-motion readings, gaan and komen generally resist prepositional PPs, but in their non-literal, aspectual readings, they generally allow such PPs. For gaan 'go', the examples in (3) and (4) illustrate this pattern. ${ }^{2} 3$

1. Throughout this paper, examples will be from Dutch unless otherwise indicated. See section 6 for some comparative notes.

2. For komen 'come', the pattern is somewhat harder to illustrate - primarily because non-aspectual komen constructions are often grammatical with prepositional non-inherently directional PPs on readings that are different from pure directional ones. Thus, hij komt (geregeld) in die kamer 'he comes (reguarly) in that room' is fine with prepositional order but then has a perfectly nonmotional interpretation ('he is regularly found in that room'), differing fundamentally from postpositional hij komt (zojuist) die kamer binnen 'he comes (just now) that room inside', which is motional and directional; and while het komt uit zijn neus 'it comes out his nose' and het komt zijn 
(3) a. *hij ging in/uit die kamer

he went in/out that room

b. hij ging die kamer in//binnen/uit

he went that room in/inside/out

'he went in(to)/out of that room'

(4) a. het gaat niet in die doos

it goes not in that box

'it does not fit into the box'

b. die vlek gaat niet uit die jas

that stain goes not out that coat

'that stain does not come off that coat'

\subsection{Manner-of-motion verbs in directional resultatives}

For manner-of-motion verbs, the empirical picture regarding the distribution of prepositional and postpositional directional PPs is more complex. Consider first of all the minimal pair in (5): whereas both sentences are grammatical (and hence seem at first blush to suggest that there is a free word-order alternation with manner-of-motion verbs between prepositional and postpositional directional PPs), $(5 a, b)$ do not support exactly the same interpretations. What is particularly relevant for our concerns here is that prepositional (5a) does not support a (literal, nonidiomatic) directional interpretation: we cannot understand vloog in (5a) literally as 'flew', with in de lucht 'in the sky' representing the plane's location at the end of the motion path. (5a) does support a (literal, non-idiomatic) locative interpretation; and it is also compatible with an idiomatic reading in which in de lucht (metaphorically) represents the plane's location at the end of the motion path (paraphrasable as 'the plane exploded'), and can thus be likened to in this respect to directional resultatives. ${ }^{4}$

neus uit 'it comes his nose out' seem to be a preP/postP minimal pair, their interpretations are different: the latter means 'it is coming out of his nose' (directional; there is also an idiomatic reading: 'he is totally fed up with it') whereas the former is best paraphrased as 'the place of origin of whatever "it" refers to is his nose', and is thus non-motional.

3. See also uit de mode gaan 'out fashion go (i.e., go out of fashion, become unfashionable)', uit de kleren gaan 'out the clothes go (i.e., take off one's clothes)', uit je bol gaan 'out your head go (i.e., go berserk)', op de bon gaan 'go on the ticket (i.e., be ticketed)'; and for komen, see in de mode komen 'in the fashion come (i.e., come into fashion, become fashionable)', in moeilijkheden komen 'in trouble come (i.e., get into trouble)', niet uit je woorden kunnen komen 'not out your words can come (i.e., be inarticulate)', niet op het woord kunnen komen 'not onto the word can come (i.e., be unable to retrieve the word from memory)'.

4. See also prepositional in (de) brand vliegen 'in (the) fire fly', which (esp. when de is left out, but for me also when $d e$ is included) supports an idiomatic non-locative interpretation (paraphrasable as 'catch fire') in which in (de) brand denotes the end point of the event denoted by the VP. 
(5) a. het vliegtuig vloog in de lucht the plane flew in the sky 'the plane flew in the sky' (locative) *'the plane flew into the sky' (directional)

b. het vliegtuig vloog de lucht in the plane flew the sky in *'the plane flew in the sky' (locative) 'the plane flew into the sky' (directional)

A particularly revealing pair (representative of a class of cases of this type) is (6a,b), with uit 'out':

(6) a. het loopt uit de hand it walks out the hand 'it gets out of hand' (idiomatic directional) *'it walks out of the hand' (non-idiomatic directional)

b. het loopt de hand uit it walks the hand out 'it walks out of the hand' (non-idiomatic directional - e.g., as said of an insect or a fluid)

*'it gets out of hand (idiomatic directional)

On its idiomatic reading, the verb in (6a) does not have its lexical manner-of-motion meaning: instead, it is basically used as a purely aspectual verb (cf. get in the English rendition of the idiom). This is true of the idiomatic reading of (5) ('explode') as well. But even on its non-idiomatic reading, (6b) does not necessarily predicate of the subject the specific manner-of-motion meaning lexically encoded by lopen 'walk': het 'it' in (6b) can, for instance, refer to oil or blood, which (because it does not have legs) cannot literally be said to be walking into the soup/out of someone's hand. ${ }^{5}$ So even on a non-idiomatic interpretation of a directional resultative construction featuring a manner-of-motion verb, the MANNER component lexically associated with the verb need not be semantically instantiated. In fact, it is often the case that the literal meaning components of the manner-of-motion verb must be absent in directional resultative constructions with manner-of-motion verbs - particularly in prepositional directional resultatives. Thus, in (7a) the pilot or the sheet of paper does not end up outside the window by agentively performing an act of flying: rather, the pilot or sheet of paper ends up outside the window by accident, for instance as a result of an explosion; in (7b), by contrast, the agentive interpretation is readily available in the case of de piloot 'the pilot'.

5. See also the idiom het bloed kruipt waar het niet gaan kan 'the blood creeps where it cannot go, i.e., blood is thicker than water': the manner-of-motion verb cannot be literally predicated of the subject. 
(7) a. de piloot/het papiertje vloog uit het raam the piloot / the sheet.of.paper flew out the window 'the pilot/sheet of paper flew out the window' (non-agentive reading only)

b. de piloot/het papiertje vloog het raam uit the pilot / the sheet.of.paper flew the window out 'the pilot/sheet of paper flew out the window' (agentive reading possible for 'pilot')

A further observation about Dutch directional resultative constructions with manner-of-motion verbs is that they often resist a prepositional order when featuring a non-inherently directional adposition (such as in or uit): (8a) can only be interpreted non-resultatively/locatively, with in het park 'in the park' identifying the location at which his strolling took place.

(8) a. hij wandelde in het park

he strolled in the park

'he strolled in (*to) the park' (locative, *directional)

b. hij wandelde het park in

he strolled the park in

'he strolled into the park' (directional, *locative)

The wandelen 'stroll' example in (8) is not an isolated case: there are lots of similar examples like them. But it is not the case that directional resultatives featuring manner-of-motion verbs are systematically impossible with prepositional order: (a) prepositional order is perfectly grammatical (and sometimes the only option) for inherently directional adpositions (see (9)); and (b) with a subset of manner-ofmotion verbs (used literally), even non-inherently directional Ps allow prepositional order in directional resultatives (10).

(9) a. hij wandelde naar het park he strolled to the park 'he strolled to the park'

b. *hij wandelde het park naar he strolled the park to

(10) a. hij sprong in het zwembad he jumped in the pool 'he jumped in(to) the pool' (locative or directional)

b. hij sprong het zwembad in he jumped the pool in 'he jumped into the pool' (directional, *locative) 


\section{The central proposal}

To account for the patterns just canvassed, I present a theory based on two central pillars - the representation of motion verb constructions in terms of $(a)$ two different aspectual operators and $(b)$ a small clause with a layered predicate consisting of a directional PP 'shell' outside a locative PP.

\subsection{The structure of locative and directional PPS}

Many of the adpositions occurring in directional PPs are not themselves intrinsically directional — whereas Dutch naar 'to' in (9) is intrinsically directional, in 'in' and $o p$ '(up)on' are basically locative adpositions which have the option of being 'used directionally'. Following my earlier work (see Den Dikken 2003, 2010), I take intrinsically directional adpositions to be lexical instantiations of $\mathrm{P}_{\text {Dir }}$ (or a head in its extended projection). On the other hand, non-directional (i.e., locative) adpositions are lexical instantiations of $\mathrm{P}_{\mathrm{Loc}}$. When such adpositions are 'used directionally', my hypothesis is that they combine with a directional PP whose null head $\mathrm{P}_{\text {Dir }}$ brings in the semantics of directionality (not inherently expressible by the locative adpositions themselves). The structure in (11) thus underlies all directional PPs, with variation residing in whether the lexical adposition spells out $\mathrm{P}_{\text {Dir }}$ or $\mathrm{P}_{\text {Loc }}$. In simple, non-circumpositional directional PPs (i.e., PPs in which just a single adpositional element is pronounced), either one of the two $\mathrm{P}$-heads in the structure in (11) thus remains silent: $P_{\text {Loc }}$ in the case of inherently directional PPs (11a), and $\mathrm{P}_{\mathrm{Dir}}$ in non-inherently directional ones (11b). In (11a), the null $\mathrm{P}_{\text {Loc }}$ is licensed straightforwardly under local c-command by $\mathrm{P}_{\text {Dir }}$; the question of how null $\mathrm{P}_{\text {Dir }}$ is licensed in (11b) will be of central concern in the discussion to follow.

$$
\left[{ }_{\mathrm{PP}} \mathrm{P}_{\mathrm{Dir}}(\ldots)\left[_{\mathrm{PP}} \mathrm{P}_{\text {Loc }} \mathrm{DP}\right]\right]
$$
a. $\left[{ }_{\mathrm{PP}} \mathrm{P}_{\mathrm{Dir}}=\right.$ OVERT $\left.\left[{ }_{\mathrm{PP}} \mathrm{P}_{\text {Loc }}=\varnothing \mathrm{DP}\right]\right] \quad \Rightarrow$ inherently directional
b. $\left[_{\mathrm{PP}} \mathrm{P}_{\mathrm{Dir}}=\varnothing\left[_{\mathrm{PP}} \mathrm{P}_{\text {Loc }}=\right.\right.$ OVERT DP $] \quad \Rightarrow$ non-inherently directional

\subsection{The GET-GO: Two aspectual operators as hosts for manner-of-motion}

Directional resultative constructions always include the structure in (11), in one of its surface instantiations. When combined with motion verbs, they serve as the predicate of the small clause in the complement of either of two aspectual/eventstructural operators: GO (as in (12)) or GET (as in (13)).

$$
\begin{aligned}
& \mathrm{GO}\left[_{\mathrm{SC}=\mathrm{RP}} \mathrm{DP}\left[\mathrm{RELATOR}=\varnothing\left[_{\text {Pred=PP }} \mathrm{P}_{\text {Dir }}(\ldots)\left[_{\mathrm{PP}} \mathrm{P}_{\text {Loc }} \mathrm{DP}\right]\right]\right]\right] \\
& \text { (13) GET }\left[_{\mathrm{SC}=\mathrm{RP}} \mathrm{DP}\left[\text { RELATOR }=\mathrm{PRT}\left[_{\mathrm{Pred}=\mathrm{PP}} \mathrm{P}_{\text {Dir }}(\ldots)\left[_{\mathrm{PP}} \mathrm{P}_{\text {Loc }} \mathrm{DP}\right]\right]\right]\right]
\end{aligned}
$$


The two structures in (12) and (13) differ in two respects: ${ }^{6}(i)$ the nature of the aspectual/event-structural operator outside the small clause: GO (pure motion) vs GET (inchoativity); and ( $i$ i) the nature of the RELATOR mediating the predication relationship between the directional PP-predicate and its subject: $\varnothing$ vs PRT. $^{7}$

To accommodate manner-of-motion constructions, the structures in (12) and (13) are readily equipped with a MANNER component adjoined to the abstract event-structural operators GO/GET. Since adjunction of a MANNER component to GO/GET is an option, not a requirement, the structures in (12) and (13) each come in two 'flavours':

(14) a. GO

$$
\left[_{\mathrm{SC}=\mathrm{RP}} \mathrm{DP}\left[\mathrm{RELATOR}=\varnothing\left[_{\text {Pred=PP }} \mathrm{P}_{\text {Dir }}(\ldots)\left[_{\mathrm{PP}} \mathrm{P}_{\text {Loc }} \mathrm{DP}\right]\right]\right]\right]
$$

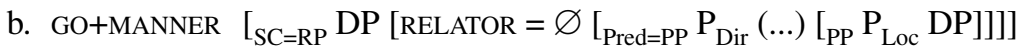

(15) a. GET

$$
\begin{aligned}
& \text { a. GET }\left[_{\mathrm{SC}=\mathrm{RP}} \mathrm{DP}\left[\text { RELATOR }=\text { PRT }\left[_{\mathrm{Pred}=\mathrm{PP}} \mathrm{P}_{\text {Dir }}(\ldots)\left[_{\mathrm{PP}} \mathrm{P}_{\text {Loc }} \mathrm{DP}\right]\right]\right]\right] \\
& \text { b. GET+MANNER }\left[{ }_{\mathrm{SC}=\mathrm{RP}} \mathrm{DP}\left[\text { RELATOR }=\text { PRT }\left[_{\mathrm{Pred}=\mathrm{PP}} \mathrm{P}_{\text {Dir }}(\ldots)\left[_{\mathrm{PP}} \mathrm{P}_{\text {Loc }} \mathrm{DP}\right]\right]\right]\right]
\end{aligned}
$$

6. The question of whether ' $(. .$.$) ' in (12) and (13) holds intervening structure between the direction-$ al and locative Ps is another variable that may differentiate between (12) and (13): specifically, it may be the case (though this is not perfectly clear to me at this time) that in (13) $\mathrm{P}_{\mathrm{Dir}}$ is always separated from $\mathrm{P}_{\text {Loc }}$ by functional structure in the extended projection of $\mathrm{P}_{\text {Loc }}$. See Den Dikken $(2003,2010)$ for discussion of the functional extended projections of locative and directional adpositions. In order not to complicate matters beyond the already high level of complexity of the maintext discussion, I will suppress all functional structure in the extended projection of $\mathrm{P}$ in this paper. (Den Dikken 2003, 2010 also argues extensively that both $\mathrm{P}_{\text {Loc }}$ and $\mathrm{P}_{\mathrm{Dir}}$ exist as separate lexical categories. I will tacitly assume so here - but it seems that nothing crucial hinges on this point in the context of the present discussion.)

7. Two things are worth noting in regard to GO and GET. First of all, these aspectual/event-structural operators should be looked upon as abstract functional categories - they do not directly correspond to the English words go and get (though go may realise GO, and get GET). GO represents directed motion (cf. Jackendoff 1990, also McIntyre 2004), and GET represents inchoativity (and could alternatively be labelled INCH or Dowtian BECOME; note the particle in Latin in-choare/incohare 'begin', Dutch ge-raken 'GE-get', German ge-raten 'GE-get', and English be-come). Secondly, the aspectual/event-structural operators GO and GET are not strictly 'subcategorised' for directional small clause complements - both can take other small clause complements as well (as in go crazy and get sick; one could conceivably try to assimilate these cases to the adpositional ones by treating the predicate as a covert PP, cf. Kayne 2008:fn. 23); but in this paper, I will focus exclusively on directional complements of GO and GET.

A reviewer asks whether the two correlated differences between (12) and (13) could not be conflated into just one: the presence in (13) and the absence in (12) of a particle. This requires a slight change of perspective: rather than saying that GET selects a particle, one would have to say that the presence of a particle in the complement of an aspectual/event-structural operator that does not introduce an external argument of its own lends the aspectual/event-structural operator the interpretation of GET. So in this way of looking at the world, GO and GET are not separate primitives: the semantic flavour of the aspectual/event-structural operator is read off the syntactic structure that it appears in. Marantz (2005) is a representative of this line of thought: for him, the meanings of 'cause', 'become' etc. 'always arise structurally'. I am very sympathetic to this line of thought, and recognise that it is more parsimonious than the approach in the text, which codifies what appears to be a single difference between (12) and (13) in two different places. I will be perfectly happy to take the labels 'GO' and 'GET' as derived rather than primitive. For ease of reference, however, it will be useful to refer to (12) as the GO structure and to (13) as the GET structure. 


\subsection{The licensing of null $P_{\text {Dir }}$}

In conjunction with the two central components just presented, what will be crucial in my account of the restrictions on prepositional order in directional resultatives will be the question of how the directional $\mathrm{P}\left(\mathrm{P}_{\text {Dir }}\right)$ that heads the small-clause predicate is licensed when it is not overtly realised. While an intrinsically directional adposition is always grammatical in all four structures in (14)-(15), a non-inherently directional adposition is grammatical in the structures in (14)-(15) only if the null $\mathrm{P}_{\mathrm{Dir}}$ that it combines with can be licensed. The leading hypothesis here is that the null $\mathrm{P}_{\text {Dir }}$ must be licensed, and that there are three ways, in principle, in which a null $\mathrm{P}_{\text {Dir }}$ can be licensed:

LICENSING OF NULL $\mathrm{P}_{\text {Dir }}$ : when $\mathrm{P}_{\text {Dir }}$ is null it must be licensed

a. via incorporation of $\mathrm{P}_{\mathrm{Dir}}$ into the event-structural operator outside the small clause

b. via incorporation of $\mathrm{P}_{\mathrm{Loc}}$ into $\mathrm{P}_{\mathrm{Dir}}$

c. by a particle under the RELATOR head of the small clause

Of these three options, plainly the simplest is (16c): no movement of any kind is involved here, in contrast to $(16 a, b)$. Licensing by a particle is possible in GET structures, which distinguish themselves from GO structures precisely in featuring a particle under the RELATOR head of the small clause. In structures exploiting (15), therefore, a non-inherently directional preposition is expected to always be legitimate. ${ }^{8}$ For directional constructions built on (14), on the other hand, either (16a) or (16b) must be resorted to whenever a non-inherently directional adposition is used. These two strategies are equally costly: each involves the construction of a single head-movement chain. ${ }^{9}$ But they have different outputs and different constraints on their applicability.

The licensing strategy in (16a) is sensitive to the question of whether the aspectual operator outside the small clause is 'bare' or plays host to an adjoined MAN-

8. Stated this way, I believe the text generalisation is entirely vindicated. But a stronger generalisation is actually expected to hold: since of the three licensing strategies, (16b) is the only one to deliver postpositional order (see the main text further below), and since (16b), involving movement, is less economical than (16c), the economy metric predicts that (manner-of-)motion verb constructions compatible with (15) should never produce postpositional order. This is accurate for Dutch ge-raken and be-landen 'get, end up' (where ge-/be-is the (affixal) PRT; cf. Hoekstra \& Mulder 1990 on be- and ver-, analysed as particles in Den Dikken 1995): in de tuin/*de tuin in geraken/belanden 'end up in the garden' (vs er ${ }^{[+\mathrm{R}]}$ in geraken/belanden. Note also English end up, which may be an explicit 'particled' instantiation of the GET+PRT structure: end up resists into (end up in (*to) the room), which follows on the assumption that into is the result of raising of $i n=\mathrm{P}_{\mathrm{Loc}}$ up to $t o=\mathrm{P}_{\text {Dir. }}$. But there do seem to be GET-based directional manner-of-motion constructions that support postpositional order. These require further discussion, which I am not capable of providing here.

9. Though incorporation of $\mathrm{P}_{\text {Dir }}$ into GO proceeds via the RELATOR, movement of $\mathrm{P}$ to $\mathrm{R}$ is substitution (see Den Dikken 2007), so $\mathrm{P}_{\text {Dir }}$-to-RELATOR-to-GO movement is successive-cyclic movement, resulting in the creation of just a single head-movement chain. 
NER component. While (14a) supports incorporation of $\mathrm{P}_{\text {Dir }}$ into GO, (14b) does not: the MANNER component and the incorporating $\mathrm{P}_{\text {Dir }}$ compete for the single adjunction position to GO that the theory countenances; (17a) and (17b), below, both violate the ban on multiple adjunction to a single host (see Kayne 1994). So while 'unmannered' (14a) allows null $\mathrm{P}_{\text {Dir }}$ to be licensed via either of two strategies in $(16 \mathrm{a}, \mathrm{b})$ (incorporation of $\mathrm{P}_{\text {Dir }}$ into $\mathrm{GO}$, or incorporation of $\mathrm{P}_{\text {Loc }}$ into $\mathrm{P}_{\text {Dir }}$ ), (14b) is ungrammatical unless $P_{\text {Loc }}$ raises to $P_{\text {Dir }}$. And importantly, as argued in Den Dikken $(2003,2010)$ and also in Gehrke (2008:sect. 4.7), raising $\mathrm{P}_{\text {Loc }}$ to $\mathrm{P}_{\text {Dir }}$ (strategy (16b)) systematically results in postpositional order: the DP-object of the raised $\mathrm{P}_{\text {Loc }}$ raises into the specifier position of the host head $\mathrm{P}_{\text {Dir }}$ (much as in Object Shift constructions, where the DP-object of the raised verb raises into the specifier position of the host head as well). ${ }^{10}$

(17) a. $*{ }_{\mathrm{GO}} \mathrm{P}_{\mathrm{Dir}}\left[\left[_{\mathrm{GO}}\right.\right.$ MANNER $[\mathrm{GO}$ GO $\left.\left.]\right]\right]$

b. $*_{\mathrm{GO}} \operatorname{MANNER}\left[\mathrm{GO}_{\mathrm{GO}} \mathrm{P}_{\mathrm{Dir}}\left[\mathrm{GO}_{\mathrm{GO}} \mathrm{GO}\right]\right]$

Adopting the structures in (14) and (15) and the predictions regarding the distribution of prepositional order in directional resultative constructions with (manner-of-)motion verbs, ${ }^{11}$ we are now fully armed to return to the Dutch data, which I will do in the next section. But first, let me briefly place the proposal outlined in this section in its historical context by briefly comparing it to the extant literature.

\subsection{Placing the main proposal in its historical context}

There are important points of overlap between the present proposal and related ideas in the literature (incl. Hoekstra \& Mulder 1990, Hale \& Keyser 1993, 2002, Mateu 2002, 2008, Snyder 2001, Harley 2005, McIntyre 2004, Borer 2005, Ramchand 2008, Son 2006, 2007, 2008, Zubizarreta \& Oh 2007, Gehrke 2008, McClure 2008).

Like Mateu's and McIntyre's proposals, the present approach is in a sense a 'plug-in' theory of 'lexical subordination': the lexically idiosyncratic MANNER component is 'plugged into' a structure that, in my view, consists solely of event-structural operators externally to the small clause, with the skeletal structure providing the complete argument structure and the 'constructional' semantics of the construction (i.e., all of the semantics except for the idiosyncratic lexical meaning of the MANNER component, which itself has no argument structure; cf. e.g. McIntyre, Borer). But whereas in Mateu's and McIntyre's theories, the lexical roots are con-

10. I assume here that movement of the complement of the raised lexical head into the specifier position of the host head is an automatic reflex of such head movement. The fact that Object Shift is apparently optional with full DPs in Insular Scandinavian has an independent cause rooted in information structure. Information-structural issues are not in effect in the context of PP-internal order.

11. In relying on licensing of null $\mathrm{P}_{\mathrm{Dir}}$ by incorporation into GO, raising of $\mathrm{P}_{\mathrm{Loc}}$ or 'Agree' with PRT, the text account has no obvious handle on directional absolutes like in de gevangenis met die verrader! 'in the prison with that traitor' (see Gehrke 2008:111). 
sistently represented as (head-level) adjuncts, my analysis allows for the possibility (discussed in more detail below) that lexical items are themselves the spell-outs of the event-structural operators outside the small clause - and in this respect, my analysis replicates a key ingredient of Hoekstra \& Mulder's (1990) analysis of directional resultatives, which treats the lexical verbs as 'copulas'. But Hoekstra \& Mulder do not employ a 'lexical subordination' analysis, treating the lexical verb consistently as an unaccusative/ergative small-clause selector, while my analysis reserves this treatment strictly for examples in which the lexical verb is detached from its regular lexical/encyclopedic meaning (i.e., cases in which the verb is basically just an event-structural operator); for sentences in which the lexical verb projects all of its lexical/encyclopedic meaning into the structure (and, as a consequence, into the semantics as well), I follow Mateu and McIntyre in representing the lexical verb as an adjunct to the event-structural operator. ${ }^{12}$

Though the present analysis represents the argument structure and core meaning of directional resultative constructions in a way that might be likened to 'constructionist' approaches of the type represented by Goldberg's (1995, et passim) work, the assumption here is emphatically not that the structures in (14) and (15) are constructional templates - they are not stored as pre-fabs but rather built in the syntax via regular instances of Merge. Thus, I strongly agree with McIntyre (2004:553) that this kind of approach differs from construction grammar 'in not giving up hope that constructions can be dissected into independently needed elements'.

My proposal sides partially with approaches to directional resultatives that treat them as 'causal' (e.g., Levin \& Rapoport 1988, Van Valin 1990:224) and partially with those (e.g., Rappaport Hovav \& Levin 2001, Kaufmann \& Wunderlich 1998) that do not: though a 'causal' analysis for e.g. John danced into the room or the bee buzzed into the room (representing them as 'John got into the room by dancing' and 'the bee got into the room by buzzing') is certainly inadequate, a 'causal' analysis of directional resultatives should not be dispensed with categorically: in section 4, I argue that it is correct for verbs like fall, and that a very similar analysis should also be adopted for directional resultatives featuring verbs such as crawl or climb; the set of 'manner-of-motion verbs' is not fully homogeneous in its behaviour in directional resultatives, and this paper argues that this is a reflex of the different ways in which the lexically idiosyncratic meaning component contributed by the verb is syntactically represented.

12. Since adjunction of MANNER involves the formation of a compound, all languages that can use manner-of-motion verbs by themselves in sentences like John swam (for x time) must allow this kind of compounding. Hence for any language that can say John swam (for x time) but does not support a directional reading for John swam under the bridge (in $x$ time), one cannot appeal to a 'macroparametric' ban on compounding (à la Snyder 2001) to rule out the directional resultative (see also Son 2007 against 'macroparametric' approaches in this context). 


\section{To GET or to GO someplace, with manners or without}

In section 2, the meaning contributions of the two basic event-structural operators for (manner-of-)motion constructions were characterised as follows: GO represents pure motion, whereas GET represents inchoativity. At this point, let us ask a more specific question: what is the key difference between the GET and GO structures featuring a MANNER component (i.e., (14b)/(15b), repeated below), interpretively?

(14) a. GO

$$
\left[_{\mathrm{SC}=\mathrm{RP}} \mathrm{DP}\left[\text { RELATOR }=\varnothing\left[_{\text {Pred=PP }} \mathrm{P}_{\text {Dir }}(\ldots)\left[_{\mathrm{PP}} \mathrm{P}_{\text {Loc }} \mathrm{DP}\right]\right]\right]\right]
$$

b. GO+MANNER

$$
\left[_{\mathrm{SC}=\mathrm{RP}} \mathrm{DP}\left[\text { RELATOR }=\varnothing\left[_{\text {Pred=PP }} \mathrm{P}_{\text {Dir }}(\ldots)\left[_{\mathrm{PP}} \mathrm{P}_{\text {Loc }} \mathrm{DP}\right]\right]\right]\right]
$$

(15) a. GET

$$
\left[_{\mathrm{SC}=\mathrm{RP}} \mathrm{DP}\left[\mathrm{RELATOR}=\mathrm{PRT}\left[\left[_{\mathrm{Pred}=\mathrm{PP}} \mathrm{P}_{\mathrm{Dir}}(\ldots)\left[_{\mathrm{PP}} \mathrm{P}_{\text {Loc }} \mathrm{DP}\right]\right]\right]\right]\right.
$$

b. GET+MANNER $\left[_{\mathrm{SC}=\mathrm{RP}} \mathrm{DP}\left[\mathrm{RELATOR}=\operatorname{PRT}\left[_{\mathrm{Pred}=\mathrm{PP}} \mathrm{P}_{\text {Dir }}(\ldots)\left[_{\mathrm{PP}} \mathrm{P}_{\mathrm{Loc}} \mathrm{DP}\right]\right]\right]\right]$

The answer I would like to give to this question is given in (18):

(18) a. in GO+MANNER structures, the MANNER component modifies the entire activity of Going

b. in GET+MANNER structures, the MANNER component modifies only the inception of the activity

This difference between (14b) and (15b), concerning the 'scope' of the MANNER component, helps us understand the differences between the examples in (19), all involving springen 'jump'.

(19) a. de vreemde man the strange man

sprong de deur/kamer uit jumped the door/room out

b. \#de vreemde man sprong uit de deur/kamer the strange man jumped out the door/room

c. de vreemde man sprong uit het raam the strange man jumped out the window

d. de houtworm/spijker sprong uit de deur the wood worm/nail jumped uit.of the door

Postpositional de deur/kamer uit springen 'jump out the door/room' in (19a) is most naturally understood as involving multiple jumps, ${ }^{13}$ all along the motion path,

13. On the single jump/multiple jumps distinction, see also Levin \& Rappaport Hovav (1995:200-1), in connection with the interpretive distinction, first observed by Jackendoff (1990:224), between (ia) and (ib), the former strongly implying a single jump and the latter strongly implying a series of jumps. Very pertinent in this connection is also Ramchand's (2008) discussion of jump in the 
hence naturally instantiates the GO+MANNER structure in (14b), with $\mathrm{P}_{\text {Dir }}$ licensed via raising of $\mathrm{P}_{\mathrm{Loc}}$ (as in (16b)), resulting in postpositional order. For an event of jumping out the door or out of the room, an interpretation in which there is a single jump that marks the inception of the process of getting out (which continues without any further jumps being made) clashes with world knowledge - we understand humans jumping out the door or out of the room to involve a series of multiple jumps, which does not mesh with a GET-based structure. ${ }^{14}$ The GET+MANNER structure in (15b) would have allowed prepositional order (with the null $\mathrm{P}_{\mathrm{Dir}}$ is licensed by the particle under the relator; recall (16c)); but the GET structure, with its meaning correlate in (18b), is infelicitous in the case of humans jumping out the door or out of the room, which explains its awkwardness of (19b).

This example should be compared to both (19c) and (19d), which are like (19b) in featuring prepositional order but unlike (19b) in being perfect. The activity described in (19c) is perfectly felicitously conceived of as involving a single jump - and being unambiguously derived via (15b) (since (14b) would have delivered postpositional order), prepositional uit het raam springen 'jump out the window' in (19c) is correctly predicted to only involve a single jump that starts off the process of getting out the window (cf. also Ramchand 2008). And similarly, it is perfectly natural to think of a situation in which the wood worm is inside the door and gets out in a single jump (assuming for the sake of argument that jumping is something that wood worms are capable of doing agentively). This reading of (19d) with houtworm 'wood worm' as the head of the subject is straightforwardly derived via (15b).

But there is a second reading for (19d) as well — the only felicitous one if inanimate spijker 'nail' is chosen as the head of the subject. On this reading, the wood worm or nail (non-literally) 'jumps' out of the door (e.g. as a result of an explosion). This is derivable via either (14a) or (15a) (the difference between them (i.e., the particle) being immaterial for the point at hand), with non-agentive springen lexicalising the event-structural operator itself. We see this non-literal, nonagentive construal of springen also in, for instance, het stoplicht springt op rood 'the traffic light turns to red'. It instantiates the 'copular' use of springen (in the sense of Hoekstra \& Mulder 1990): springen in this reading does not represent an adjoined MANNER component; in fact, on this non-literal, non-agentive reading of uit de deur springen, there is no MANNER component involved at all.

field ('punctual' only) vs jump into the field ('punctual' or 'activity' — my 'single jump'/'multiple jumps').

(i) a. jump into someone's arms

b. jump one's way into someone's arms

14. This may go along with what we find for trekken 'pull': over de streep trekken 'pull over the line' can involve one single pull starting off the transition from being on one side of the line to being on the other side of the line ('get someone/something across the line by pulling') whereas \# over de brug trekken 'pull over the bridge' would, under normal circumstances (i.e., given our knowledge of the normal world), have to involve continuous imparting of force all along the motion path - though note that this time the MANNER component is clearly a modifier of CAUS, not GO, so it is not clear in this case why it should affect prepositionality. See section 5, below, for explicit discussion of the possibility of adjoining the MANNER component to CAUS. 
The difference between representing an adjoined MANNER component or lexicalising the event-structural operator (GET/GO) itself manifests itself also in our earlier examples in (5). World knowledge leads us to understand vliegen 'fly' qua MANNER modifier as involving (18a), not as (18b). So the GET-based structures in (15) are unavailable for a literal MANNER reading of the examples in (5): such a reading must avail itself of (14b), the GO+MANNER structure. Postpositional (5b) is readily derived via (14b), with raising of $\mathrm{P}_{\text {Loc }}$ to $\mathrm{P}_{\text {Dir }}$ resulting (via Object Shift) in postpositional order. But prepositional (5a) is not derivable this way, hence fails on a literal MANNER reading of vliegen 'fly'. It does, however, support a non-literal reading, with vliegen not being construed as an adjoined MANNER component but instead as a lexicalisation of the event-structural operator in the 'unmannered' a-structures in (14)/(15).

The fact that not all apparent manner-of-motion verbs have a structurally represented MANNER component (as shown by examples of the type represented by (5a) and (19d)) provides support for the postulation of an autonomous MANNER component alongside event-structural operators. Verbs like vliegen 'fly' and springen 'jump' can be used in an 'unmannered' way, as pure aspectual operators; but they can also instantiate a MANNER component adjoined to an event-structural operator, in which case they receive a literal interpretation expressing the manner in which the event comes about.

This difference between representing an adjoined MANNER component and lexicalising the event-structural operator itself applies as well to 'plain' gaan 'go' and komen 'come'. ${ }^{15}$ Whenever literal 'going' is involved, only postpositional orders are allowed with gaan ' $\mathrm{go}$ ' if $\mathrm{P}_{\mathrm{Dir}}$ is null. ${ }^{16}$ This we see in the examples in (3) and (4), partially repeated below in (20): (20a) involves literal 'going', and resists prepositional order because the MANNER component adjoined to GO is incompatible with incorporation of null $\mathrm{P}_{\text {Dir }}$ into GO; postpositional (20a') is well-formed because raising of $\mathrm{P}_{\mathrm{Loc}}$ to $\mathrm{P}_{\mathrm{Dir}}$ licenses the latter; and prepositional (20b) is grammatical because gaan 'go' represents not MANNER but GO itself here.

(20) a. *hij ging in die kamer he went in that room

$a^{\prime}$.hij ging die kamer in/binnen he went that room in/inside 'he went into that room'

b. het gaat niet in die doos it goes not in that box 'it does not fit into the box'

15. In the interest of space, the case of komen will continue to remain unillustrated.

16. Of course, when $\mathrm{P}_{\mathrm{Dir}}$ is itself overt, (14b) is licensed with literal 'going', and delivers prepositional order: door de tunnel gaan 'go through the tunnel', over de schutting gaan 'go over the fence'. 
Importantly, abstract event-structural GO differs from concrete go in not having an 'orientation' component. Literal, concrete go (or gaan in Dutch) typically differs from literal, concrete come (or komen in Dutch) with respect to the orientation of the path (usually, go involves movement away from the speaker, while come involves movement towards the speaker; this difference is perhaps most clearly visible in imperatives: come to me/ ${ }^{\sharp}$ her! vs. go to her ${ }^{\#} m e$ !). This difference in orientation is contributed by the MANNER component adjoined to abstract GO, which itself has no orientation component: it represents pure motion. For the 'plain' motion verbs go and come (and Dutch gaan 'go' and komen 'come'), the MANNER component is presumably nothing more than 'orientation'. But even though the MANNER component for these 'plain' motion verbs may be minimal, it is important to realise that $g o$ and come themselves ARE in fact manner-of-motion verbs (when used literally, not aspectually): like lexically 'richer' manner-of-motion verbs such as fly, they feature a MANNER component attached to the event-structural operator; and it is the presence of this adjoined MANNER component that prevents, in Dutch, the licensing of prepositional order in (20a).

\section{On manners, means, and causes}

All of the examples instantiating the GO structure in (14b) discussed in section 3 indisputably involve a MANNER component that cannot felicitously be construed as the cause or instrument of the event - he jumped/ran out of the room is felicitously paraphrased as he went out of the room jumping/running (with a gerundial free adjunct), not (typically) as he got out of the room by jumping/running (with a by-phrase). Many directional manner-of-motion constructions are not 'causal', and should not represent the MANNER component as a causal adjunct (cf. Rappaport Hovav \& Levin 2001, Kaufmann \& Wunderlich 1998, contra e.g. Levin \& Rapoport 1988, Van Valin 1990:224, where John danced into the room is represented as 'John got into the room by dancing'). But there do seem to be 'manner-of-motion' directionals for which a 'causal' representation is right.

The clearest case of this type involves the verb vallen 'fall':

(21) a. hij viel uit het raam

he fell out the window

'he fell out the window'

b. hij viel in het zwembad

he fell in the pool

'he fell into the pool'

There are two important differences between *uit/*in de kamer rennen 'run out of/into the room' and uit het raam/in het zwembad vallen 'fall out the window/into the pool': $(a)$ prepositional order is grammatical in the latter but not in the former, and $(b)$ falling causes one to go out the window/into the pool, whereas running does not. Thus, (21a) is naturally paraphrased not as (22a) but as (22b): 
(22) a. "hij ging vallend het raam uit
he went falling the window out
\# 'he went out the window falling'
b. hij geraakte/belandde uit het raam door te vallen $\rightarrow$ MANNER
he got/ended up out the window by to fall
'he ended up outside by/because of falling'

The modifier vallen 'fall' hence does not seem to represent a MANNER component but rather the cause of what happens. It is plausible that the causation component of complex GO events is not structurally represented as an adjunct to GO. For concreteness, I propose that the causative source structure of fall out the window represents the cause as the complement of a (null) causative preposition relatively low in the structure, as in my fingers frozelare blue from the cold (where the cause is the complement of from, not the external argument of a causative light verb $v_{\text {CAUS }}$ ). So what would underlie fall out the window would be something like "GO out the window FROM fall' (structural details omitted). Representing fall out the window as a causative construction in this manner will preserve unaccusative syntax (evident, for

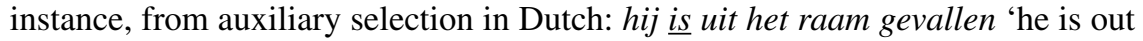
the window fallen'). It will also allow incorporation of null $\mathrm{P}_{\text {Dir }}$ in vallen constructions, licensing prepositional order in (21). ${ }^{17}$

A second type of case for which a MANNER paraphrase seems less than appropriate and which, like the case of vallen 'fall', allows prepositional order in directionals with non-inherently directional Ps is illustrated by (23):

(23) het konijn kroop/klom uit/in z'n holletje

the rabbit crept/climbed out/in its hole.dim

'the rabbit crept out of/into its hole'

This example is not analogous to uit het raam springen 'jump out the window'. The lexically idiosyncratic meaning component contributed by the verb in these sentences clearly does not modify only the inception of the event: it applies throughout the motion path. In this respect, (23) is different from (21) as well. But (23) is not perfectly similar to *uit/*in de kamer springen/rennen vs de kamer uit/in springen/rennen 'jump/run out of/into the room' either — and in this respect, it behaves like the vallen cases in (21). ${ }^{18}$ While de kamer uit/in springen/rennen 'jump/run

17. Representing fall out the window this way also allows us to answer the question (raised by a reviewer) of how the cause can amalagamate with the aspectual verb to form vallen 'fall': it raises up to GO from the FROM-PP. In connection with the syntax of causation, also note McIntyre's (2004:548) 'INIT', 'covering eventive notions like CAUSE and DO, but also stative relations like "is the initiator/source of"'. Besides from-causatives, there may be other unaccusative causative constructions as well (see Larson \& Cheung 2008): psych-verb constructions like please are unaccusative in Dutch and Italian. On from-causatives, see Alexiadou et al. (2006) and references cited there.

18. Note that the issue here is not one of directed/undirected motion: 'run' and 'crawl' are both inherently undirected (on English run and its undirected default interpretation, see Levin \& Rappaport Hovav 1995:210). 
out of/into the room' is periphrastically paraphrasable with the MANNER component as a free-adjunct present participle (recall English he went out of the room jumping/running), for (23a) the lexical meaning component contributed by the verbs is best paraphrased with the aid of a door 'by' phrase: (24a) is not infelicitous per se but does not seem to adequately paraphrase (23a).

a. "het konijn kwam kruipend uit z'n holletje $\rightarrow$ MANNER the rabbit came creeping out its hole.DIM (\# as paraphrase of (23a)) \#'the rabbit got out of the hole crawling'

b. het konijn kwam uit z'n holletje door te kruipen $\rightarrow$ MEANS the rabbit came out its hole.DIM by to creep 'get out of the hole by (means of) crawling'

The additional meaning component of rennen 'run' is naturally classified as a MANNER component; running is certainly not a MEANS prerequisite to getting out of or into a particular spot: if running allows you to do this, then surely walking will, too. But the additional meaning component of kruipen 'creep' does seem to represent a MEANS component - as suggested by the use of door/by (means of) in the paraphrase in (24b). ${ }^{19}$ If this is a fundamental distinction, then one would seek to explain the difference between uit/in het holletje kruipen 'crawl out of/into the hole' and *uit/*in de kamer rennen 'run out of/into the room' in terms of a difference in attachment between MEANS and MANNER components: probably, while MANNER components are adjoined directly to the event-structural operator (GET/GO), MEANS components are attached to a syntactic projection of the eventstructural operator, as a result of which incorporation of null $\mathrm{P}_{\text {Dir }}$ into naked GO is readily available in MEANS constructions, and prepositional order is grammatical (alongside postpositional order). ${ }^{20} \mathrm{I}$ offer this suggestion tentatively. But in any event, simply placing MANNER, CAUSE and MEANS on the same tier (as does Talmy 1985 for 'MANNER/CAUSE') is arguably not a good idea: the Dutch data just reviewed indicate that MANNER behaves markedly differently from CAUSE/MEANS.

19. Also see the actual examples below, culled from the Internet:

(i) a. In eukaryotic cells, locomotion occurs by means of crawling, gliding or beating of cilia.

b. Infants around seven to nine months begin to move themselves in the environment by means of crawling, which opens up a whole new world of exploration for them.

c. Although weak from the operation, he was still keen to get to the convention, by means of crawling across the hospital floor.

20. On the possibility that lexically idiosyncratic meaning components associated with motion verbs can be adjoined to a syntax projection of the event-structural operator, see the discussion of Romance in section 6 . 


\section{Where are your manners? - The causative/inchoative alternation}

One of the central ingredients of the proposal advanced in this paper is the idea that manner-of-motion verbs (on their literal manner-of-motion readings) are characterised by the adjunction of a MANNER component to the event-structural operator — as in the b-structures in (14) and (15), repeated here (along with their 'unmannered' a-variants):

(14) a. GO

$$
\left[_{\mathrm{SC}=\mathrm{RP}} \mathrm{DP}\left[\text { RELATOR }=\varnothing\left[_{\text {Pred=PP }} \mathrm{P}_{\text {Dir }}(\ldots)\left[_{\mathrm{PP}} \mathrm{P}_{\text {Loc }} \mathrm{DP}\right]\right]\right]\right]
$$

b. GO+MANNER

$$
\left[_{\mathrm{SC}=\mathrm{RP}} \mathrm{DP}\left[\mathrm{RELATOR}=\varnothing\left[_{\mathrm{Pred}=\mathrm{PP}} \mathrm{P}_{\text {Dir }}(\ldots)\left[_{\mathrm{PP}} \mathrm{P}_{\text {Loc }} \mathrm{DP}\right]\right]\right]\right]
$$

(15) a. GET

$$
\left[_{\mathrm{SC}=\mathrm{RP}} \mathrm{DP}\left[\text { RELATOR }=\mathrm{PRT}\left[\left[_{\mathrm{Pred}=\mathrm{PP}} \mathrm{P}_{\text {Dir }}(\ldots)\left[_{\mathrm{PP}} \mathrm{P}_{\text {Loc }} \mathrm{DP}\right]\right]\right]\right]\right.
$$

b. GET+MANNER $\left[_{\mathrm{SC}=\mathrm{RP}} \mathrm{DP}\left[\right.\right.$ RELATOR $\left.\left.=\operatorname{PRT}\left[_{\mathrm{Pred}=\mathrm{PP}} \mathrm{P}_{\mathrm{Dir}}(\ldots)\left[_{\mathrm{PP}} \mathrm{P}_{\mathrm{Loc}} \mathrm{DP}\right]\right]\right]\right]$

The structure in (14b) is incompatible with prepositional order in Dutch whenever $\mathrm{P}_{\text {Dir }}$ is null (i.e., not lexically instantiated by an inherently directional adposition). This was made to follow from the fact that licensing of null $\mathrm{P}_{\text {Dir }}$ in (14b) succeeds only via raising of $\mathrm{P}_{\text {Loc }}$ to $\mathrm{P}_{\text {Dir }}$ (raising of $\mathrm{P}_{\text {Dir }}$ to modified Go being illegitimate), which yields postpositional order (via Object Shift). In (15b), by contrast, prepositionality is grammatical because $\mathrm{P}_{\text {Dir }}$ is licensed in situ by the presence of PRT under the RELATOR head, pre-empting the need for raising of $\mathrm{P}_{\text {Loc }}$ to $\mathrm{P}_{\text {Dir }}$.

Nothing else said, the prediction that is made by this account is that prepositional order should be categorically forbidden in directional resultatives featuring a null $\mathrm{P}_{\text {Dir }}$ with manner-of-motion verbs whose MANNER component applies throughout the motion path. This prediction is, as far as I am aware, entirely accurate for intransitive (unaccusative/ergative) directional resultatives of this type. But interestingly, there is a striking difference between intransitive and transitive variants with respect to the (un)availability of prepositional resultatives with non-intrinsically directional Ps - seen in alternations such as the following: ${ }^{21}$

(25) a. de auto reed $\{*$ in de garage/de garage in $\} \quad \rightarrow$ intransitive: post-P only 'the car "drove" into the garage'

b. hij reed de auto $\{$ in de garage/de garage in $\} \rightarrow$ transitive: pre-P and 'he drove the car into the garage' post-P both okay

21. Throughout, the prepositional versions of the intransitive examples are only ill-formed on the intended directional interpretation of the PPs - as always, a locative interpretation for these PPs (in which case they are adjuncts to the PP) is readily available (but this is entirely irrelevant to the point under scrutiny). The diacritics in the a-examples relate to the intended, directional interpretations of these sentences; the English prose translations of the examples further serve to highlight their intended directionality. 
(26) a. de boot voer $\left\{{ }^{?} *_{\text {in }}\right.$ de sluis/de sluis in $\}$ 'the boat sailed into the lock'

b. hij voer de boot $\{$ in de sluis/de sluis in $\}$ 'he sailed the boat into the lock' $\rightarrow$ intransitive: post-P strongly preferred

$\rightarrow$ transitive: pre-P and post-P both okay

This can in fact be accounted for straightforwardly by the proposal that a MANNER component is an adjunct to an event-structural operator.

In the intransitive case, adjoining a MANNER component to GO (as in (14b)) prevents, as we have seen, incorporation of null $\mathrm{P}_{\text {Dir }}$ into GO, hence forces raising of $\mathrm{P}_{\mathrm{Loc}}$ up to $\mathrm{P}_{\text {Dir, }}$, yielding postpositional order. But in the transitive case, which adds a CAUS head above GO, the MANNER component can in principle be adjoined either to GO or to CAUS - as in $(27 \mathrm{a}, \mathrm{b})$ :

(27) a. CAUS

$\left[\right.$ GO+MANNER $\left[_{\mathrm{SC}=\mathrm{RP}} \mathrm{DP}\left[\mathrm{RELATOR}=\varnothing\left[_{\mathrm{Pred}=\mathrm{PP}} \mathrm{P}_{\text {Dir }}(\ldots)\right.\right.\right.$ $\left.\left.\left.\left.\left[{ }_{\mathrm{PP}} \mathrm{P}_{\text {Loc }} \mathrm{DP}\right]\right]\right]\right]\right]$

b. CAUS+MANNER [GO

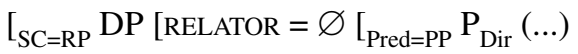

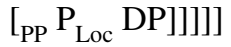

Of course (27a) continues to force postpositional order with a null $\mathrm{P}_{\text {Dir }}$. But in (27b), null $\mathrm{P}_{\text {Dir }}$ is welcome to incorporate into unmodified GO. So the grammaticality of the prepositional (25b) and (26b) can be straightforwardly accounted for by assigning it the structure in (27b), with MANNER adjoined to CAUS.

For verbs which show event-to-event homomorphism (a homomorphic mapping of the causing and moving events, with the two unfolding together; Krifka 1998), including drag, carry, schlep, tug, lower, the MANNER component cannot be adjoined to just GO or CAUS - instead, MANNER must be associated with both GO and caus (as in (28a)). This predicts, correctly, that Dutch verbs of this type resist prepositional directionals (see $\left(28 \mathrm{~b}, \mathrm{~b}^{\prime}\right)$ ), while verbs like gooien 'throw' (showing no homomorphism) allow prepositional order (recall (1a)).

(28) a. drag-type 'homomorphic' verbs

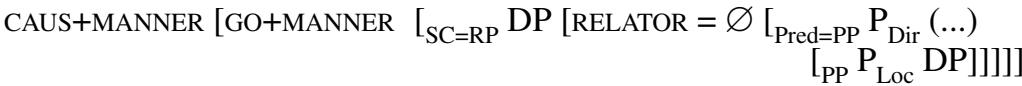

b. hij sleepte/droeg de bal op het veld

he dragged/carried the ball on the field

'he dragged/carried the ball (while) on the field' (locative)

*'he dragged/carried the ball onto the field' (*directional)

$b^{\prime}$.hij sleepte/droeg de bal het veld op he dragged/carried the ball the field on 'he dragged/carried the ball onto the field'

Note also that if Dative Shift involves the incorporation of a null dative $\mathrm{P}$ into the head selecting the dative small clause (as argued in Den Dikken 1995), and if $\mathrm{P}$-incorporation into a complex head resulting from MANNER adjunction is forbid- 
den (recall (17)), it is predicted that verbs of the drag type (homomorphic) should resist Dative Shift, whereas non-homomorphic verbs that have MANNER adjoined just to CAUS (so not to GO) should allow it - a prediction that directly derives Pinker's (1989) generalisation: ${ }^{22}$
(29) a. he dragged the ball to Mary
cf. he threw the ball to Mary
b. *he dragged Mary the ball
he threw Mary the ball

Importantly, without the decomposition of manner-of-motion verbs into an event-structural operator (GET/GO) and an autonomous MANNER component, there is no sensible way to analyse pairs of the type illustrated in (25)-(26). If, say, varen 'sail' is a monolithic verb selecting the small clause, then why should it matter whether there is a CAUS head present outside the projection of zeilen when it comes to the licensing of the null $\mathrm{P}_{\text {Dir }}$ heading the small-clause predicate? Since there is no direct structural relationship between CAUS and $\mathrm{P}_{\text {Dir, }}$, it would be a complete mystery (on the non-decompositional approach) that the two interact the way they do in (25)-(26). The pairs in (25)-(26) thus provide strong support for the idea that the MANNER component is autonomously represented, as an adjunct to some appropriate event-structural operator in the clause - and that, whenever there is more than one such event-structural operator, there is, in principle, a choice of hosts for the MANNER component. ${ }^{23}$

22. See also Levin (1993). But note Bresnan \& Nikitina's work on the dative alternation as a 'gradient', non-categorical one - see e.g. Bresnan \& Nikitina (2007).

23. The transitive/intransitive contrast in (25)-(26) with respect to the allowability of prepositional order is not the only contrast between transitive and intransitive motion verbs. In postpositional (i), the intransitive allows relativisation of de garage (as in (iia)) but the transitive does not (see (iib)); similarly with varen 'sail', as shown in (iii)-(iv). (For the observation, see A Modern Grammar of Dutch; for a case-related account see Den Dikken 2003.) Though this is another instance of transitive/intransitive contrasts in the domain of motion verbs, it does not relate directly to the placement of the MANNER component. Rather, the key here seems to be the fact that in the transitive examples, $v=$ CAUs fails to attract the $w h$-operator associated to de garage/de boot onto its edge because there is an intervener: accusative de auto and de boot, respectively. Thus, (iib) and (ivb) arguably instantiate an intervention effect: $v=$ CAUS case-agrees with de auto/de boot, hence fails to attract the likewise accusative $w h$-operator onto its edge.

(i) a. de auto reed de garage in

b. Jan reed de auto de garage in

(ii) a. de garage die de auto in is gereden 'the garage that the car "drove" into'

b. *de garage die Jan de auto in heeft gereden 'the garage that Jan drove the car into'

(iii) a. de boot voer de sluis in

b. de kapitein voer de boot de sluis in

(iv) a. de sluis die de boot in is gevaren 'the lock that the boat sailed into'

b. "?de sluis die de kapitein de boot in heeft gevaren 'the lock that the captain sailed the boat into' 


\section{Going beyond Dutch}

The foregoing discussion has concentrated virtually exclusively on Dutch (which is the language for which I control the complex empirical data best). But directional resultatives are obviously not exclusive to Dutch — though different languages realise them differently, and place different kinds of restrictions on their distributions. In this section, because of space restrictions, I will be only able take a brief look at verb serialisation in Altaic and West-African languages, and at manner-of-motion resultatives in the Romance languages and English. ${ }^{24}$

\subsection{Serialisation}

Levin \& Rappaport Hovav (1995:185) (attributing their data to Yoneyama 1986) observe that Japanese agentive manner-of-motion verbs 'cannot take goal phrases directly; however, they may combine with the verb iku 'go' or another verb of inherently directed motion to form complex verbs that can take goal phrases'.

(30) a. ?John-wa ekie-e hashitta
John-TOP station-to ran
b. ?John-wa kishi-e oyoida
John-TOP shore-to swam
(31) a. John-wa ekie-e hashitte-itta
John-TOP station-to running-went
'John ran to the station'
b. John-wa kishi-e oyoide-itta
John-TOP shore-to swimming-went
'John swam to the shore'

These Japanese facts can be readily understood as instantiating the full lexicalisation of the GO+MANNER structure for directional resultatives whose MANNER component applies throughout the motion path: hashitte 'running' and oyoide 'swimming' are the spell-outs of the MANNER component, and itta lexicalises the event-structural operator GO that hosts the MANNER component. ${ }^{25}$

24. For some useful comparative notes on directional resultatives, see Ramchand \& Svenonius (2007), and references cited there.

25. A reviewer asks how Japanese V-V compounds such as kake-agaru 'run-go.up', kake-mawaru 'run-go.around', hai-agaru 'crawl-go.up' and hai-deru 'crawl-go.out' (discussed in Tsujimura 2001:374) can be accounted for. The reviewer suspects that these might be problematic because they seem to involve both (i) incorporation of $\mathrm{P}_{\mathrm{Dir}}$ into GO and (ii) MANNER adjunction to GO, in apparent violation of (17). My response to this is that it is not the case that the $\mathrm{V}-\mathrm{V}$ compounds just mentioned involve incorporation of $\mathrm{P}_{\mathrm{Dir}}$ into GO - rather, the verbal elements that serve as spellouts of the event-structural operator (agaru, mawaru, and deru) include in their inherent lexical baggage a semantic component that licenses either a null particle in the RELATOR head of the small clause in its complement or a null $\mathrm{P}_{\text {Dir }}$. No incorporation is taking place. See also the discussion of İgbo and Yorùbá V-V compounds below. 
The facts of Korean are similar in some respects. ${ }^{26}$ In (32), the event-structural operator is once again spelled out independently of the MANNER component (i.e., MANNER and the operator do not conflate): $k a$ 'go' in (32a) transparently lexicalises GO. This time, however, the MANNER component and the event-structural operator do not seem to form a complex word: instead, they form a serial verb construction.
a. ku-nun changmwun-pakk-ulo nal-a ka-ass-ta he-TOP window-outside-towards fly-E go-PST-DECL 'he flew out the window'
b. *ku-nun changmwun-ul he-TOP window-ACC
nal-a ka-ass-ta
fly-E go-PST-DECL
(Korean)

We see such serialisation also in (33), where kenn 'cross' is lexically 'rich' enough to allow the complex structure formed by the incorporation of the locative $\mathrm{P}$ into the directional P (cf. (16b)) to remain phonologically unrealised in its entirety.

(33) ku-nun kang-ul heyemchi-e kenn-ess-ta

(Korean) he-TOP river-ACC swim-E cross-PST-DECL

'he swam across the river'

The sentences in (34) and (35) are the counterparts of Korean (33) in İgbo and Yorùbá (two West-African serialising languages), respectively: ${ }^{27}$

(34) ó gwú-fè-rè mmǐlí

3SG hit-cross-ASP water

(İgbo)

'he swam across the river'

(35) ó wè odò já

3sG dunk river cut.through

(Yorùbá)

'he swam across the river'

The example in (34) involves a ' $\mathrm{V}-\mathrm{V}$ compound', with the two parts of the serial verb construction being 'glommed together', much as in Korean; (35) is a serial verb construction 'proper', featuring the 'shared object' (in the sense of Baker 1989) in between the two verbs. In both West-African languages, the GO operator is spelled out by something that is lexically 'rich' enough to license a null P ( $f \grave{e}$ 'cross' and já 'cut.through', respectively), again as in Korean (33). The MANNER component in İgbo (34) forms a unit with the GO operator ('swim' in İgbo is 'hit

26. See Lee (1991, 1992), Déchaine (1993:331-36), Son (2006, 2007, 2008), Zubizarreta \& Oh (2007) for discussion of Korean directional resultatives, which will not be exhaustively reviewed below. Thanks to Ji Young Shim and Minjeong Son for discussion of the Korean data presented here.

27. Thanks to Victor Manfredi for supplying these examples, and for giving me valuable insights into their properties. See also Son (2008) for similar examples of serialisation in Malayalam. 
water'); in Yorùbá (35) it is a separate verb in a serialising construction - just as in Korean, independent of and higher than the GO operator.

What is the position of this independent MANNER component in these serial verb constructions? A promising line of thought would treat MANNER here as an adjunct to DO, the 'light verb' introducing the agent of agentive constructions:

$$
\ldots\left[\mathrm{DO}+\mathrm{MANNER}\left[\mathrm{GO}\left[_{\mathrm{SC}=\mathrm{RP}} \mathrm{DP}\left[\mathrm{RELATOR}=\varnothing\left[_{\mathrm{Pred}=\mathrm{PP}} \mathrm{P}_{\mathrm{Dir}}=\varnothing(\ldots)\left[_{\mathrm{PP}} \mathrm{P}_{\mathrm{Loc}}=\varnothing \mathrm{DP}\right]\right]\right]\right]\right.\right.
$$

This approach may give us a purchase on the difference between serialising languages, on the one hand, and non-serialising languages, on the other: serialising languages allow (36) because they can license GO directly, by spelling it out overtly; non-serialising languages do not allow (36) because they cannot string overt verbs together (so GO cannot be licensed by being spelled out ${ }^{28}$ ), and null GO in (36) cannot incorporate into MANNER-modified Do because doing so would incur a violation of the ban on multiple adjunction (recall (17)). Non-serialising languages must hence adjoin the MANNER component to GO, as before, whereas serialising languages have the possibility of representing MANNER as an adjunct to the agentive 'light verb' Do. ${ }^{29}$

\subsection{Romance}

If (36) is the right way of representing the MANNER component in serialising manner-of-motion constructions, then in all cases reviewed in this paper so far, the MANNER component is a head-level modifier of some event-structural operator. But both (36) and (27b) (from section 5, above) indicate that the MANNER component is relatively autonomous vis-à-vis GO. And of course we know independently that MANNER does not have to be represented as a head-level modifier of an event-structural operator: in the periphrastic paraphrases given in section 4 ( $g o$ out of the room running, get out of the hole by crawling etc.), MANNER is a phraselevel modifier (a free adjunct or a by-PP), adjoined to a syntactic projection of GO or GET.

28. The roots of the cross-linguistic distribution of verb serialisation remain less than fully understood. What probably plays a central role in this is the ability for (overt) verbs to be realised in contexts in which they are not local to tense - thus, note that English-type languages do not allow bare-verbal depictives (John ate the meat nude vs. *John ate the meat sing vs. John ate the meat singing), a fact discussed against the background of the T-chain theory of verb licensing by Guéron $\&$ Hoekstra (1995).

29. This is not to say that non-serialising languages categorically forbid MANNER adjunction to DO in fact, they most certainly do allow for this, but only in simple structures in which no incorporation into DO+MANNER takes place. Arguably, MANNER adjunction to DO is the right way to treat simple unergative manner verbs, like dance in I could have danced all night - here dance represents an activity, not motion towards a goal. No small-clause complementation is involved, no GO, no null $\mathrm{P}_{\text {Dir }}$ or anything of the sort. If one so desires, one can take the MANNER component adjoined to the activity verb DO to end up there via incorporation from the complement of DO (as Hale \& Keyser 1993 suggested, based on the facts of Basque egin 'do'). This will not be relevant for our purposes here. 
As is well known, in some languages, projection of the MANNER component in this fashion is virtually the only way of accommodating MANNER in directional resultatives — the Romance languages are cases in point. ${ }^{30}$

(37) a. Marie a couru dans la maison

(French)

Marie has run in the house

'Marie ran in(*to) the house' (locative, *directional ${ }^{31}$ )

b. Marie est entrée dans la maison en courant

Marie is entered in the house in running

'Marie ran in*(to) the house' (directional, *locative)

(38) a. Maria corrió en la casa

Maria ran in the house

(Spanish)

'Maria ran in(*to) the house' (locative, *directional)

b. Maria entró corriendo a la casa

Maria entered running to the house

'Maria ran in*(to) the house' (directional, *locative)

I do not have the space here to discuss the Romance facts in detail. Suffice it to make a few remarks against the background of the central proposal advanced in this paper.

Recall first of all the structures in (14)-(15), repeated here once again:

(14) a. GO

$$
\left.\left[_{\mathrm{SC}=\mathrm{RP}} \mathrm{DP} \text { [RELATOR }\left[_{\text {Pred=PP }} \mathrm{P}_{\text {Dir }}(\ldots)\left[_{\mathrm{PP}} \mathrm{P}_{\text {Loc }} \mathrm{DP}\right]\right]\right]\right]
$$

b. GO+MANNER

$$
\left.\left[_{\mathrm{SC}=\mathrm{RP}} \mathrm{DP} \text { [RELATOR }\left[_{\text {Pred=PP }} \mathrm{P}_{\text {Dir }}(\ldots)\left[_{\mathrm{PP}} \mathrm{P}_{\text {Loc }} \mathrm{DP}\right]\right]\right]\right]
$$

(15) a. GET

$$
\left[_{\mathrm{SC}=\mathrm{RP}} \mathrm{DP}\left[\mathrm{RELATOR}=\mathrm{PRT}\left[_{\text {Pred=PP }} \mathrm{P}_{\text {Dir }}(\ldots)\left[_{\mathrm{PP}} \mathrm{P}_{\text {Loc }} \mathrm{DP}\right]\right]\right]\right]
$$

b. GET+MANNER $\left[_{\mathrm{SC}=\mathrm{RP}} \mathrm{DP}\left[\mathrm{RELATOR}=\mathrm{PRT}\left[_{\mathrm{Pred}=\mathrm{PP}} \mathrm{P}_{\mathrm{Dir}}(\ldots)\left[_{\mathrm{PP}} \mathrm{P}_{\mathrm{Loc}} \mathrm{DP}\right]\right]\right]\right]$

One important way in which Romance differs from Germanic is that (15) in Romance does not actually feature the particle in a syntactically autonomous position as the head of the verb's small-clause complement. Romance does not have (productive) analytical verb-particle constructions; particle verbs are arguably generated as lexical units in these languages (cf. French devenir 'become'). With the

30. It would certainly be a gross simplification to say that Romance categorically resists directional resultatives with manner-of-motion verbs - thus, Italian is well known to have Gianni è corso a casa 'Gianni is run to home, i.e., Gianni ran home' and Gianni è saltato dalla finestra 'Gianni is jumped from-the window' (see Folli 2001 and references there for details on Italian, and see also Mateu 2002 on Catalan, Burnett \& Tremblay 2009 on Old French, and Bouchard 1995 on current French). On auxiliary selection in these directional resultatives, see the end of section 7, below.

31. Ramchand \& Svenonius (2007) report that for some speakers (37a) apparently does support a directional interpretation. 
particle in Romance finding itself in a position base-adjoined to GET, the GET structure cannot license null $\mathrm{P}_{\mathrm{Dir}}$ via strategy (16c): the small-clause phase is in between the licensee (null $\mathrm{P}_{\mathrm{Dir}}$ ) and its prospective licenser (the particle).

A second difference between Romance and Germanic is that in Romance, there is no (productive) 'copular' construal (in the sense of Hoekstra \& Mulder 1990) of manner-of-motion verbs, in the typical case: that is, as a general rule, Romance manner-of-motion verbs cannot spell out GO/GET. So (14a) in Romance typically cannot merge verbs meaning 'run' or 'float' directly under GO.

And thirdly, in Romance, there are no postpositions, which may indicate that there is no movement of $\mathrm{P}_{\text {Loc }}$ up to $\mathrm{P}_{\text {Dir }}$ in these languages. If so, this means that all directional PP complements (except those that have a lexical spell-out of $\mathrm{P}_{\text {Dir }}$ ) involve a null $\mathrm{P}_{\mathrm{Dir}}$ in need of licensing 'from above' (because licensing 'from below', via raising of $\mathrm{P}_{\mathrm{Loc}}$, fails). But the structures that would, in Germanic, allow one to license null $\mathrm{P}_{\text {Dir }}$ 'from above' with manner-of-motion verbs (i.e., the GET structures in (15)) are unavailable for manner-of-motion directional resultatives in Romance for independent reasons; and neither can Romance (productively) merge a manner-of-motion verb directly under the event-structural operator (GO/GET), construing it 'copularly'. Hence, Romance as a general rule does not allow mannerof-motion verbs to combine with directional resultatives featuring non-inherently directional Ps at all. ${ }^{32}$

The way to render Germanic-type manner-of-motion directional resultatives in Romance is typically by representing the MANNER component syntactically as an adjunct to a syntactic (extended) projection of the event-structural operator (GO), as in the b-examples in (37) and (38) (see also Spanish la botella entró a la cueva flotando 'the bottle went into the cave floating'; Talmy 1985), rather than as an adjunct to the aspectual operator itself (as in Germanic). ${ }^{33}$

32. It should be noted, however, that Bouchard (1995) points out that French sauter sous le pont 'jump under the bridge' is ambiguous between a locative and a directional reading. This may suggest that French does, under certain circumstances, license null $\mathrm{P}_{\text {Dir }}$ in (15b). Bouchard also reports that nagé sous le pont 'swim under the bridge' and courir derrière la maison 'run behind the house' support directional readings (while floter sous le pont 'float under the bridge' does not). For these we need (14b), which apparently licenses null $\mathrm{P}_{\text {Dir }}$ occasionally in French as well. The behaviour of 'to' ( $a$ in French, and $a$ elsewhere in Romance) is a further complication (recall correre a casa 'run home'); it is imaginable that 'to' in Romance can under certain circumstances spell out $\mathrm{P}_{\text {Dir' }}$, but the nature of this preposition needs to be better understood in a number of ways before firm conclusions can be drawn.

33. Thinking of Snyder (2001), one might want to relate the difference between adjunction of MANNER to the event-structural operator itself (Germanic) and adjunction of MANNER to a syntactic (extended) projection of the event-structural operator (Romance) to the fact that Romance lacks productive compounding: perhaps as a consequence of this, Romance would be unable to merge a MANNER component with an event-structural operator at the level of the head. But Mateu's work has critiqued Snyder's (2001) compounding parameter — see e.g. Mateu (2008:245, fn. 26). Son $(2007,2008)$ also rejects any kind of 'macroparametric' approach to the differences between languages in the domain of resultative constructions, arguing, directly in line with the spirit of the present work, that the variation in this domain is better understood in terms of more microscopic properties of individual ingredients of directional (manner of) motion constructions. 


\subsection{English}

Finally, let me make a few remarks on English directional resultatives with mannerof-motion verbs: ${ }^{34}$

(39) a. he jumped in the pool

b. he jumped into the pool

(40) a. he fell in the pool

b. he fell into the pool

(41) a. he ran/walked in the room

b. he ran/walked into the room

(42) a. he danced/waltzed in the room

b. he danced/waltzed into the room (locative, directional)

(directional, *locative)

(locative, directional)

(directional, *locative)

(locative, directional)

(directional, *locative)

(locative, $*$ directional)

(directional, *locative)

Both (39a) and (40a) can be straightforwardly analysed with the aid of the GET structure in (15b): the MANNER component modifies only the inception of the motion path; and the presence of a particle under the RELATOR head is sufficient to license the null $\mathrm{P}_{\text {Dir }}$ (the null counterpart to the to portion of into in the b-sentences) in situ. The examples in (41a) and (42a) cannot be mapped onto the GET structure in (15b), however: the MANNER component must here apply to the entire motion path, so these examples involve either of the GO structures in (14). The difference between run/walk on the one hand, and dance/waltz on the other, when it comes to the distribution of 'bare' in (in particular, the fact that 'bare' in supports a directional reading in (41) but not in (42)) should thus be explained with reference to (14).

I would like to suggest that the allowability (for many speakers) of (41a) as a directional construction is a consequence of the fact that (for those speakers) run and walk can be construed as instantiations of GO itself - that is, (41a) qua direction-

34. Nichols (2008) observes (following in the footsteps of Jespersen's 1952 correlation between the loss of inflection and the rise of zero derivation/conflation in the history of English) that the number of manner-of-motion verbs taking directional resultative complements in English increases dramatically at the point at which English finally loses inflection on its infinitives. By the end of the 15th century, English possessed a fairly small number of manner verbs with what Nichols calls 'inherent forward motion' (IFM), such as creep, crawl, float, flow, ride, row, run and swim, which could combine with directional complements; but after the complete loss of verbal inflection (in particular, infinitival inflectional morphology), English significantly increased the possibilities for directional complements to manner-of-motion verbs by allowing such complements with mannerof-motion verbs (overwhelmingly in a conversion relationship with nouns) that lack IFM, such as dance, hop and hover. Nichols provides an account of this observation in terms of a zero-derivation analysis of the latter type of manner-of-motion verbs. I will not attempt to derive the observation about the spread of non-inherently directional manner-of-motion verbs with directional complements from the present proposal. 
al is based on (14a), with incorporation of null $\mathrm{P}_{\mathrm{Dir}}$ into unmodified GO. ${ }^{35}$ For dance and waltz, on the other hand, their lexical richness prevents them from being construed 'copularly', as a lexicalisation of the GO operator: these are not a 'light verbs' in any reasonable sense of that term. So to (42a), (14b) must apply, and as a result, null $\mathrm{P}_{\text {Dir }}$ is not licensable via incorporation into GO (recall (17)). The fact that English has no postpositions (which I take to mean, as I did in the case of Romance, that $\mathrm{P}_{\text {Loc }}$ cannot raise to null $\mathrm{P}_{\text {Dir }}$ to license it) and the fact that no particle is available to license null $\mathrm{P}_{\text {Dir }}$ in situ (since (42) is not plausibly based on a GET structure) now conspire with the ban on incorporation of null $\mathrm{P}_{\text {Dir }}$ into 'mannered' GO to render null $\mathrm{P}_{\mathrm{Dir}}$ entirely unlicensable in directional constructions with dance or waltz. There is no choice but to spell $\mathrm{P}_{\text {Dir }}$ out overtly in (42), therefore, which explains why only (42b) (with to as the spell-out of $\mathrm{P}_{\mathrm{Dir}}$ ) is grammatical.

The idea that English locative in can be used directionally only if the null $\mathrm{P}_{\text {Dir }}$ that it combines with is licensed via incorporation into the event-structural operator selecting the small clause is strikingly confirmed by the observation (made in Thomas 2001 and reported in Gehrke 2008:106) that directional in-PPs may not be separated from the verb: while (41a) supports a directional reading, (44) is directional only with to included, and that the Locative Inversion construction in (45) is ungrammatical with 'bare' in:

(44) a. he ran at top speed in the room

b. he ran at top speed into the room (locative, *directional)

(directional, *locative)

$$
\text { in*(to) the room ran John }
$$

The ungrammaticality of (45) is a simple consequence of the fact that, even with run construed 'copularly', $\mathrm{P}_{\mathrm{Dir}}$ incorporation into GO is blocked in the Locative Inversion

35. English run is 'light' in expressions such as the well/source ran dry or the car ran out of gas, which do not involve a MANNER component contributed by the lexical meaning of run. Synchronically, English walk does not seem to have (m)any clearly 'copular' or 'light' uses (in contradistinction to its Dutch counterpart, lopen, which has many such uses). The $O E D$ lists a number of 'light' uses of walk that are now obsolete (e.g., 'be rife, widespread', 'progress', 'go about in public'); it also mentions walk in in the sense of 'arrive, enter (esp. unexpectedly or with surprising ease)', which does not have to involve the MANNER lexically specified by 'heavy' walk (cf. love walked in), and also walk into as 'arrive (in an awkward situation) through unwariness' and walk out on 'desert, withdraw from', which again involve no literal walking, and may instantiate walk as GO.

Ramchand (2008:Chapter 5, fn. 1) points out that walk in the room (for many speakers) fairly easily supports a directional interpretation and walk in the door supports this reading particularly readily, whereas walk in the park does not (hence is strictly locative), and draws attention to the significance of what she calls a 'threshold-crossing interpretation'. How to translate this into a structural representation remains unclear at this time.

The difference between walk/run and dance/waltz highlighted by English (41)/(42) represents itself in Malayalam as a difference between simple PP-complementation (in the case of walk/run) versus serialisation (with Go spelled out as poy 'go'); see Son (2008) and references there. This goes along with the text suggestion that walk/run in English (41) is used 'copularly', spelling out GO, and that dance/waltz cannot so do. 
construction because of the fact that the directional PP is taken out from the c-command domain of the event-structural operator. ${ }^{36}$

\section{In closing}

The analysis of MANNER modification as adjunction to (a projection of) an eventstructural operator and the hypothesis that apparent manner verbs can, under certain circumstances, serve as lexicalisations of these event-structural operators can be readily extended to positional verbs (as seen in (46)), with the positional verb either representing an adjoined manner component to BE (the aspectual operator relevant in the positional domain; see (47b)) or being construed a copula, in the sense of Hoekstra \& Mulder (1990), spelling out BE itself (as in (47a); the righthand examples in (46) are likely candidates for 'copular' construal).

(46) a. he was lying on the couch

b. she was sitting on the sofa

c. they were standing on the corner

d. the clothes were hanging on the line it is hanging in the balance

(47) a. BE

$$
\begin{array}{ll}
\text { a. } \mathrm{BE} & {\left[_{\mathrm{SC}=\mathrm{RP}} \mathrm{DP}\left[\text { RELATOR }\left[_{\text {Pred=PP }} \mathrm{P}_{\text {Loc }} \mathrm{DP}\right]\right]\right]} \\
\text { b. BE+MANNER } & {\left[_{\mathrm{SC}=\mathrm{RP}} \mathrm{DP}\left[\text { RELATOR }\left[_{\text {Pred=PP }} \mathrm{P}_{\text {Loc }} \text { DP }\right]\right]\right]}
\end{array}
$$

Other event-structural/aspectual operators, besides GO, GET, and BE, include CAUS and DO - the former introducing cause(r)s and the latter introducing agents. These, too, are eligible for MANNER modification: recall (27b) and (36). Thus MANNER adjunction pervades the entire clausal syntax.

Clausal syntax itself is, at bottom, purely a matter of functional, event-structural operators (GET, GO, BE, CAUS, DO). So-called lexical verbs are, whenever they 'assert' their lexical/encyclopedic meanings, represented as modifiers of one of these event-structural operators. It is (a subset of) these event-structural operators, in conjunction with their small-clause complements, that structurally represent the argument structures of clauses (cf. also Baker 1997, Hale \& Keyser 1993, Pylkkänen 2002, Borer 2005, McIntyre 2004). There is no sense in which 'lexical verbs' themselves have argument structure representations: lexical entries for verbs are truly minimal (cf. Borer 2005; also McIntyre 2004, for conflation cases).

More specifically, there is no obvious sense in which a verb is either ergative/unaccusative or unergative: the only 'verbs' are the abstract event-structural

36. Den Dikken (2006) explicitly allows for 'beheaded' Locative Inversion in several languages —as in Norwegian $\left[_{\mathrm{PP}} t_{\mathrm{P}}\right.$ brevet $]$ ble klistret frimerker på $t_{\mathrm{PP}}$ 'the letter was pasted stamps on, i.e. stamps were pasted on the letter'. In such cases $\mathrm{P}$ clearly moves overtly, with its trace being licensed prior to Locative Inversion. In the case at hand, however, P-incorporation is covert and bled by Locative Inversion. (Thanks to Gui-Sun Moon for raising this issue.) 
operators; the lexical items themselves either spell out these operators (in which case they 'are' ergative/unaccusative if the operator is) or they are adjuncts to these operators (in which case they are not ergative/unaccusative). This makes the account of auxiliary selection in directional resultative manner-of-motion constructions entirely straightforward: since GO and GET are ergative/unaccusative (i.e., do not introduce an external argument), such constructions will always show be-selection in aux-selecting languages; the lexical verbs themselves (i.e., the MANNER modifiers) do not 'select' any auxiliary at all: rather, auxiliary choice is determined by the event-structural operator, which in manner-of-motion constructions is always ergative/unaccusative.

(48) a. Jan is/*heeft $\langle$ uit $\rangle$ het raam 〈uit $\rangle$ gesprongen
Jan is/has out the window out jumped
'Jan jumped out the window'
b. Gianni è/*ha corso a casa
Gianni is/has run to home
'Gianni ran home'

There is no need, from this point of view, for any lexical specification of unaccusativity/ergativity for any lexical verbs - nor for lexical or syntactic manipulation thereof (or multiplicity of lexical entries, as in the Levin \& Rappaport Hovav 1995 polysemy approach) or for syntactic 'ergative shift' (as in Hoekstra \& Mulder's 1990 proposal). ${ }^{37}$

37. It is sometimes thought that ergativity/unaccusativity $v s$ unergativity is diagnosed by the distribution of (impersonal) passives and agent-oriented adverbs like deliberately. But the latter could of course at best only be a diagnostic for a subset of unergatives: the agentive ones. And even then it fails: Dutch (ia) is clearly unaccusative/ergative, as witness zijn 'be' selection; yet the agent-oriented adverb met opzet 'on purpose' is perfectly legitimate; in (ib), met opzet cannot possibly depend on a (sentence-internally represented) agent: samenvallen 'coincide' does not introduce an agent.

(i) a. ik was met opzet gevallen

I was on purpose fallen

'I fell on purpose'

b. het afscheid viel met opzet samen met de aandeelhoudersvergadering the good-bye fell on purpose together with the stockholders-meeting

'the farewell party was deliberately scheduled to coincide with the stockholders meeting'

Relatedly, the impersonal passive diagnostic is clearly not a test for unergativity or even agentivity. Examples like Perlmutter's (1978) (ii) have often been interpreted as indicating that, in order for impersonal passivisation to work with a verb like vallen 'fall, that verb must be construed agentively ('to fall on purpose'), thereby becoming (more) like an unergative verb (we know, after all, that the agent role is never projected VP-internally, to a complement).

(ii) in het tweede bedrijf werd er door de acteur precies op het juiste moment gevallen in the second act was there by the actor precisely at the right moment fallen 'in the second act, the actor fell precisely on cue' 


\section{References}

Alexiadou, Artemis; Anagnostopoulou, Elena; Schäfer, Florian (2006). "The properties of anticausatives cross-linguistically”. In: Frascarelli, Mara (ed.). Phases of interpretation. Berlin: Mouton de Gruyter, pp. 187-212.

Baker, Mark (1989). "Object sharing and projection in serial verb constructions". Linguistic Inquiry 20: 513-553.

Baker, Mark (1997). “Thematic roles and syntactic structure”. In: Haegeman, Liliane (ed.). Elements of grammar. Dordrecht: Kluwer, pp. 73-137.

Borer, Hagit (2005). The normal course of events. Structuring sense. Vol. II. Oxford: Oxford University Press.

Bouchard, Denis (1995). The semantics of syntax: A minimalist approach to grammar. Chicago: University of Chicago Press.

Bresnan, Joan; Nikitina, Tatiana (2007). "The gradience of the dative alternation". To appear in: Uyechi, Linda; Hee Wee, Lian (eds.). Reality exploration and discovery: Pattern interaction in language and life. Stanford: CSLI Publications.

Burnett, Heather; Tremblay, Mireille (2009). "Variable-behavior Ps and the location of PATH in Old French". In Aboh, Enoch; van der Linden, Elisabeth; Quer, Josep; Sleeman, Petra (eds.). Romance languages and linguistic variation. Amsterdam: John Benjamins, pp. 25-50.

Chomsky, Noam (1995). The minimalist program. Cambridge, MA: MIT Press.

Déchaine, Rose-Marie (1993). Predicates across categories: Towards a category-neutral syntax. Dissertation. Amherst: University of Massachusetts.

Dikken, Marcel den (1995). Particles: On the syntax of verb-particle, triadic and causative constructions. Oxford/New York: Oxford University Press.

Dikken, Marcel den (2003). "On the syntax of locative and directional adpositional phrases”. Ms., CUNY Graduate Center (earlier version of Den Dikken 2010).

Dikken, Marcel den (2006). Relators and linkers. On the syntax of predication, predicate inversion, and copulas. Cambridge, MA: MIT Press.

The problem with the idea that, in order for a (Dutch) verb to support impersonal passivisation, it must be construed agentively is that it is simply false: impersonal passives like those in (iii) are perfect, and evidently non-agentive. It must be concluded, therefore, that impersonal passivisation is not a diagnostic for either agentivity or unergativity.

(iii) a. er wordt wat af gestorven tegenwoordig there is what off died nowadays 'people die by the bushel these days'

b. er wordt wat af gezeten in de Europese kerkgebouwen there is what off sat in the European chuch-buildings 'there is a lot of sitting going on in European churches'

c. er wordt wat af gevallen in het wielerwereldje there is what off fallen in the cyclist-world.DIM '(speed) cyclists are falling a lot'

d. er werd door de sneeuwval aan de lopende band gevallen/uitgegleden/geslipt there was because-of the snow-fall on the conveyor belt (i.e., constantly) fallen/out-sli$\mathrm{ded} /$ skidded 'because it was snowing, lots of people were falling/sliding/skidding'. 
Dikken, Marcel den (2007). "Phase Extension: A reply. Reaction to commentaries on 'Phase Extension: Contours of a theory of the role of head movement in phrasal extraction'". Theoretical Linguistics 33: 133-63.

Dikken, Marcel den (2010). "On the functional structure of locative and directional PPs”. In Cinque, Guglielmo; Rizzi, Luigi (eds.), Mapping spatial PPs. Oxford/New York: Oxford University Press.

Dikken, Marcel den; Sybesma, Rint (1998). Take serials light up the middle. Ms, CUNY Graduate Center \& University of Leiden.

Folli, Raffaella (2001). Constructing telicity in English and Italian. Ph.D. dissertation, University of Oxford.

Gehrke, Berit (2008). Ps in motion: On the semantics and syntax of P elements and motion verbs. Dissertation, Utrecht University.

Goldberg, Adele (1995). Constructions. Chicago: University of Chicago Press.

Guéron. Jacqueline; Hoekstra, Teun (1995). "The temporal interpretation of predication”. In Cardinalletti, Anna; Guasti, Maria Teresa (eds.), Small clauses. San Diego: Academic Press, pp. 77-107.

Hale, Kenneth \& Samuel Jay Keyser. 1993. On argument structure and the lexical expression of syntactic relations. In Kenneth Hale \& Samuel Jay Keyser (eds), The view from Building 20. Cambridge, MA: MIT Press. 53-104.

Hale, Kenneth; Keyser, Samuel Jay (2002). Prolegomenon to a theory of argument structure. Cambridge, MA: MIT Press.

Harley, Heidi (2005). "How do verbs get their names? Denominal verbs, manner incorporation, and the ontology of verb roots in English". In: Erteschik-Shir, Nomi; Rapoport, Tova (eds.). The syntax of aspect: Deriving thematic and aspectual interpretation. Oxford: Oxford University Press, pp. 42-64.

Hoekstra, Teun; Mulder, René (1990). "Unergatives as copular verbs: Locational and existential predication". The Linguistic Review 7: 1-79.

Jackendoff, Ray (1990). Semantic structures. Cambridge, MA: MIT Press.

Jespersen, Otto (1952). Growth and structure of the English language. 9th edition. London: Blackwell.

Kaufmann, Ingrid; Wunderlich, Dieter (1998). "Cross-linguistic patterns of resultatives". Theorie des Lexikons. Arbeiten des SFB 282. \#109.

Kayne, Richard (1994). The antisymmetry of syntax. Cambridge, MA: MIT Press.

Kayne, Richard (2008). "Antisymmetry and the lexicon". Linguistic Variation Yearbook 8: 1-31.

Krifka, Manfred (1998). “The origins of telicity”. In: Rothstein, Susan (ed.). Events and grammar. Dordrecht: Kluwer, pp. 197-235.

Larson, Richard; Cheung, Candice (2008). Make as a triadic unaccusative. Paper presented at the LSA Annual Meeting, Chicago.

Levin, Beth (1993). English verb classes and alternations: A preliminary investigation. Chicago: University of Chicago Press.

Levin, Beth; Rapoport, Tova (1988). "Lexical subordination". CLS 24: 275-89.

Levin, Beth; Rappaport Hovav, Malka (1995). Unaccusativity. At the syntax-lexical semantics interface. Cambridge, MA: MIT Press.

Marantz (2005). Objects out of the lexicon: Objects as events. Ms., MIT (downloadable as http://web.mit.edu/marantz/Public/Vienna/Vienna.pdf). 
Mateu, Jaume (2002). Argument structure. Relational construal at the syntax-semantics interface. Dissertation, Universitat Autònoma de Barcelona.

Mateu, Jaume (2008). "On the l-syntax of directionality/resultativity: The case of Germanic preverbs". In Asbury, Anna; Dotlačil, Jakub; Gehrke, Berit; Nouwen, Rick (eds.). Syntax and semantics of spatial P. Amsterdam: John Benjamins, pp. 221-250.

McClure, William (2008). "Change of state grammar and unaccusativity”. Ms., Queens College and The Graduate Center, CUNY.

McIntyre, Andrew (2004). "Event paths, conflation, argument structure, and VP shells". Linguistics 42: 523-571.

Nichols, Lynn (2008). "When deriving is (re)coining: Manner of motion verbs in English and morphological type". Ms., University of California, Berkeley.

Perlmutter, David (1978). "Impersonal passives and the unaccusative hypothesis". BLS 4: 157-89.

Pinker, Steven (1989). Learnability and cognition: The acquisition of argument structure. Cambridge, MA: MIT Press.

Pylkkänen, Liina (2002). Introducing arguments. Ph.D. dissertation, MIT.

Ramchand, Gillian (2008). Verb meaning and the lexicon: A first phase syntax. Cambridge: Cambridge University Press.

Ramchand, Gillian; Svenonius, Peter (2007). "Licensing directional interpretations: Summary of results from MRA seminars in 2005-6”. Ms., CASTL, University of Troms $\varnothing$.

Rappaport Hovav, Malka; Levin, Beth (2001). "An event structure account of English resultatives". Language 77: 766-97.

Snyder, William (2001). "On the nature of syntactic variation". Language 77: 324-42.

Son, Minjeong (2006). "Directed motion and non-predicative PathP in Korean". In: Svenonius, Peter (ed.). Nordlyd, Troms $\phi$ Working Papers in Language \& Linguistics 33:2, special isue on adpositions. University of Troms $\varnothing$, pp. 176-99.

Son, Minjeong (2007). "Directionality and resultativity: The cross-linguistic correlation revisited". In: Bašić, Monika; Pantcheva, Marina; Son, Minjeong; Svenonius, Peter (eds.). Nordlyd, Troms $\phi$ Working Papers in Language \& Linguistics 34:2, special issue on space, motion, and result. University of Troms $\varnothing$, pp. 126-64.

Son, Minjeong (2008). "The typology of directed motion from a micro-parametric perspective". Paper presented at the 18th Congrès International des Linguistes/International Congress of Linguists, Seoul, July 2008.

Talmy, Leonard (1985). "Lexicalization patterns: Semantic structure in lexical forms". In: Shopen, Timothy (ed.). Language typology and syntactic description. Vol. III: Grammatical categories and the lexicon. Cambridge: Cambridge University Press, pp. 57-149.

Thomas, Emma (2001). "On the expression of directional movement in English". Essex Graduate Student Papers in Language and Linguistics 4: 87-104.

Tsujimura, Natsuko (ed.) (2001). The handbook of Japanese linguistics. Oxford: Blackwell.

Van Valin, Robert (1990). "Semantic parameters of split intransitivity". Language 66: 221-60.

Yoneyama, Mitsuaki (1986). "Motion verbs in conceptual semantics". Bulletin of the Faculty of Humanities 22. Tokyo: Seikei University, pp. 1-15.

Zubizarreta, Maria Luisa; Oh, Eunjeong (2007). On the syntactic composition of manner and motion. Cambridge, MA: MIT Press. 